Необходимо добавить, что если вопрос о правовом статусе физических и юридических лиц в чрезвычайных ситуациях привлекает повышенное внимание и часто является предметом исследований, то правовой статус государственных органов и государственных служащих, работающих в чрезвычайных ситуациях, в настоящее время изучен недостаточно. внутреннее право. В теории науки не до конца разработаны определения правового статуса спасателей, недостаточно раскрыта проблема характера и содержания правового статуса спасателей.

Таким образом, можно сделать вывод о том, что для упорядочения и совершенствования правовых норм требуется унификация и закрепление законодательства об обязательном государственном страховании отдельных категорий граждан в единый правовой акт. В законодательстве, регулирующем обязательное государственное страхование, необходимо закрепить цели, задачи, принципы, общие условия и порядок обязательного страхования работников.

$$
* * *
$$

1. Федеральный закон от 22.08.1995 N 151-Ф3 (ред. от 01.07.2021) «Об аварийно-спасательных службах и статусе спасателей».

2. Федеральные авиационные правила «Аварийно-спасательное обеспечение полетов воздушных судов» от 26.11.2020 N 517 .

\title{
Орозбаева Б.А. \\ Получение квалифицированной юридической помощи как гарантированное право граждан
}

Ошский государственный юридический институт (Кыргызстан, Ош)

doi: 10.18411/trnio-01-2022-189

\section{Аннотация}

В данной статья на основе общенаучных методов познания проанализированы содержательные стороны нормативного закрепления оказания квалифицированной юридической помощи. Проведен нормативный анализ закрепления права оказания квалифицированной юридической помощи. Обозначены актуальные вопросы данного института и его характерные признаки.

Ключевые слова: Конституция, квалифицированная юридическая помощь, адвокат, уголовное судопроизводство, гарантия, уголовно процессуальный кодекс.

\section{Abstract}

In this article on the basis of general methods of knowledge analysis are analyzed the content of the normative fixation provision of qualified legal assistance. Conducted a normative analysis of the fixation of the right to a qualified legal aid. It is marked by topical issues of this institute and its characteristic features.

Keywords: Constitution, qualified legal aid, lawyer, criminal proceedings, guarantee, criminal procedure code.

Понятийный аппарат юриспруденции является наиболее мало исследований областью юриспруденции. Именно исследования основных дефиниций, понятий, категорий правового регулирования даст возможность полноценного регулирования соответствующих общественных отношений.

В соответствии с законом Кыргызской Республики «О нормативно-правовых актах» статья 4 говорится «что при осуществлении нормотворчества процесса необходимо должно соблюдаться доступность языка нормативно-правового акта. 
А в статье 11 данного нормативно правового акта есть требование которое гласит что при разработке нормативно правового акта необходимо избегать чрезмерно обобщенных или чрезмерно детализированных формулировок.

Основной закон страны Конституция Кыргызской Республики закрепляет право на квалифицированную юридическую помощь как основное гарантированное право человека.

Пункт 5 статьи 59 Конституции Кыргызской Республики гласит, что «С момента задержания лицу обеспечивается безопасность, предоставляется возможность защищать себя лично, пользоваться квалифицированной юридической помощью адвоката, а также право на медицинский осмотр и помощь врача»

Данная гарантия закреплена в статье 61 новой Конституции Кыргызской Республики, которая гласит: «Каждый имеет право на квалифицированную юридическую помощь. В случаях, предусмотренных законом, юридическая помощь оказывается за счет государства» [1].

Кыргызстан как социально павовое государство обеспечивает каждому гражданину Кыргызской Республики охрану прав и совбод от любых преступных посягательств.

Квалифицированная юридическая помощь как социальное благо позволяет гражданам эффективно защищать свои права и свободы в различных правовых отношениях (гражданского, административного, уголовного).

Законодательное закрепление понятия квалифицированной «юридической помощи» не нашел должного закрепления в части нормативно-содержательной стороны.

В Конституции Кыргызской Республики понятия «квалифицированной юридической помощи» не содержит критерии должного качественного оказания самой юридической помощи и ее субъектов.

В юридической литературе имеются разносторонние взгляды содержания понятийного аппарата «квалифицированной юридической помощи».

Несмотря на это Закон Кыргызской Республики от 16 декабря 2016 года № 201 “О гарантированной государством юридической помощи” [2]. содержит понятие квалифицированной юридической помощи. Согласно статье 4 данного закона «Квалифицированная юридическая помощь - профессиональная деятельность адвоката по представлению или защите законных прав и интересов физических лиц за счет государства в гражданском, административном и уголовном судопроизводстве на всех стадиях гражданского, административного и уголовного судопроизводства»;

Данное нормативное закрепление «квалифицированной юридической помощи» носит статутные характеристики субъектов, видов судопроизводства.

Необходимо отметить, что понятийный аппарат, нормативное закрепление «квалифицированной юридической помощи» до недавнего времени считался малоисследованной областью.

В последнее время интерес понятийному аппарату, законодательному закреплению, реализацию оказания квалифицированной юридической помощи уделяется большое внимание. Имеется труды на диссертационном уровне А.Г Манафов Ю Ф.Панченко и другие.

А также исследованы понятийный аппарат данного института исследованы учеными М. Б. Костровой, Г.М Резником, О П. Мелешко, Ю.Г Кипселиди и другими.

В современных условиях правового развития гражданская активность реализации права на получение квалифицированной помощи значительно усиливается.

Особенно в условиях рыночных отношений к данной помощи в первую очередь нуждаются социально незащищенные, уязвимые люди, несовершеннолетние, инвалиды и женщины.

Государство, гарантируя данную помощь должен выработать механизмы расширения спектра юридических услуг, отвечающих требованиям времени оказывать юридическую помощь. 
Наиболее действенным механизмом оказания квалифицированной юридической помощи остается институт адвокатуры. Поскольку адвокаты, будучи активными участниками различных правоотношений и форм судопроизводства, остаются одним из активных участников реализации данного права.

В недавно принятом Уголовно-процессуальном кодексе [3] также установлен ряд руководящих принципов получения квалифицированной юридической помощи. При этом термин «защитник» заменен словом «адвокат» в целях обеспечения единообразия понятийного аппарата и оказания квалифицированной помощи.

Но наравне с этим в части организационно-правовой части оказания квалифицированной юридической помощи в Кыргызстане еще не создана целостная институциональная система для оказания квалифицированной юридической помощи. Причины - нехватка финансовых ресурсов, ведомственных подразделений и отсутствие продуманной государственной политики. По количеству адвокатов- основных субъектов квалифицированной юридической помощи - Кыргызстан отстает от многих стран.

Возможности других организаций и физических лиц, оказывающих юридическую помощь (общественных и правозащитных организаций, профсоюзов, юридических клиник, общественных приемных, информационно-правовых центров, омбудсменов), используются не в полной мере.

Законодательство, регулирующее механизм реализации права на юридическую помощь, не соответствует современным требованиям, является непрочным и требует доработки.

К сожалению, на сегодняшний день перед отечественной юриспруденцией не поставлена задача, разработать научно обоснованную концепцию комплексной системы юридической помощи. Представители науки уголовно-процессуального права и гражданского процессуального права обычно ограничиваются анализом правового статуса участников процесса.

В настоящее время ряд вопросов можно назвать актуальными проблемами оказания квалифицированной помощи являются;

- оценка соответствия законов Кыргызстана международным стандартам оказания юридической помощи;

- изучение международного опыта по оказанию правовой помощи;

- разработка концептуальных предложений, направленных на совершенствование механизма оказания квалифицированной юридической помощи в Кыргызской Республике.

Обобщая научную статья об оказании квалифицированной юридической помощи можно констатировать что данное право ;

- признано гарантированным правом каждого гражданина;

- безвозмездно представляется;

- доступность каждому гражданину.

Наравне с этим при оказании услуг квалифицированной юридической помощи;

- не предусмотрены минимальные стандарты юридической помощи;

- недостаточное сочетание передового опыта международной практики оказания квалифицированной юридической помощи;

- не до конца разработаны научно обоснованные концепции получения квалифицированной юридической помощи.

1. Конституция Кыргызской Республики от 5 мая 2021 года № 59.

2. Закон КР от 16 декабря 2016 года № 201 “О гарантированной государством юридической помощи”.

3. Уголовно-процессуальный кодекс Кыргызской Республики от 28 октября 2021 года № 126. 